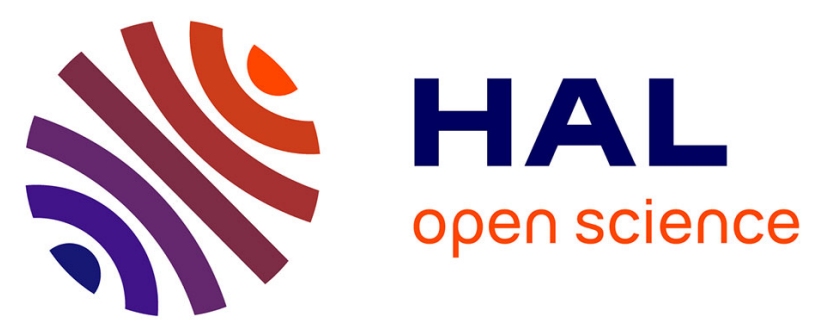

\title{
From the cradle of grapevine domestication: molecular overview and description of Georgian grapevine (Vitis vinifera L.) germplasm
}

Seren Imazio, David Maghradze, Grabriella de Lorenzis, Roberto Bacilieri, Valerie Laucou, Patrice This, Attilio Scienza, Osvaldo Failla

\section{To cite this version:}

Seren Imazio, David Maghradze, Grabriella de Lorenzis, Roberto Bacilieri, Valerie Laucou, et al.. From the cradle of grapevine domestication: molecular overview and description of Georgian grapevine (Vitis vinifera L.) germplasm. Tree Genetics and Genomes, 2013, 9 (3), pp.641-658. 10.1007/s11295013-0597-9 . hal-01268000

\section{HAL Id: hal-01268000 https://hal.science/hal-01268000}

Submitted on 29 May 2020

HAL is a multi-disciplinary open access archive for the deposit and dissemination of scientific research documents, whether they are published or not. The documents may come from teaching and research institutions in France or abroad, or from public or private research centers.
L'archive ouverte pluridisciplinaire HAL, est destinée au dépôt et à la diffusion de documents scientifiques de niveau recherche, publiés ou non, émanant des établissements d'enseignement et de recherche français ou étrangers, des laboratoires publics ou privés. 


\title{
From the cradle of grapevine domestication: molecular overview and description of Georgian grapevine (Vitis vinifera $\mathrm{L}$.) germplasm
}

\author{
Serena Imazio - David Maghradze • Gabriella De Lorenzis • \\ Roberto Bacilieri • Valérie Laucou • Patrice This • \\ Attilio Scienza • Osvaldo Failla
}

Received: 9 February 2012 /Revised: 5 September 2012 / Accepted: 2 January 2013

(C) Springer-Verlag Berlin Heidelberg 2013

\begin{abstract}
Historical information and archaeological and palaeobotanical findings point Georgia, in the South Caucasus, as a cradle for grapevine (Vitis vinifera L.) domestication from its wild form ( $V$. vinifera silvestris Beck.) and subsequent selection and development of varieties with characters suitable for human consumption. The hypothesis of Georgia being a center of domestication, combined with its distance from western countries and the importance of its viticulture and wine production, make Georgian grape
\end{abstract}

Communicated by G. G. Vendramin

Electronic supplementary material The online version of this article (doi:10.1007/s11295-013-0597-9) contains supplementary material, which is available to authorized users.

\section{S. Imazio}

Dipartimento di Scienze della Vita, Università di Modena e Reggio Emilia, Via Amendola 2, Padiglione Besta,

Reggio Emilia 42122, Italy

\section{S. Imazio $(\bowtie)$}

Centro Interdipartimentale Siteia Biogest, Università di Modena Reggio Emilia, Via Amendola 2, Padiglione Besta,

Reggio Emilia 42122, Italy

e-mail: serenaanna.imazio@unimore.it

D. Maghradze

Institute of Horticulture, Viticulture and Oenology,

6 Marshal Gelovani Ave., Tbilisi 0159, Georgia

G. De Lorenzis $\cdot$ A. Scienza $\cdot$ O. Failla

Dipartimento di Scienze Agrarie e Ambientali, Università degli Studi di Milano, Via Celoria 2, Milano 20133, Italy

R. Bacilieri $\cdot$ V. Laucou $\cdot$ P. This

INRA Montpellier SupAgro, UMR AGAP, Equipe DAVEM,

2 Place Viala, Montpellier 34060, France germplasm particularly interesting to be investigated under the genetic point of view. Twenty nuclear microsatellite loci were used to genotype 112 Georgian grapevine accessions ( $V$. vinifera sativa Beck.) from germplasm collections and 18 from spontaneous growing plants ( $V$. vinifera silvestris Beck.) found in wild conditions and to compare them to a large international cultivar collection in France. Data analysis shows that Georgian grapevine germplasm has maintained distinctive traits despite arrival of international, foreign varieties and still conserve characteristics of local breeding linked to traditional wine production regions of the country. Results have identified alleles, overall loci, well represented in the Georgian germplasm (cultivated and wild) and absent or poorly represented in other countries, highlighting uniqueness and originality of traits of this viticulture. Moreover, the search for relationships between Georgian and foreign viticulture has evidenced few interesting cases linking the Georgian varieties with Western European ones and with neighboring Caucasian countries, helping to identify the real place of origin in some doubtful cases. In addition, populations or sparse individuals of wild grapevine still preserved in the Georgian natural environments present smaller genetic distances with local cultivars than in other European regions. Principal component analysis (PCA) has also identified special overlapping of the wild compartment with some cultivated varieties. This work provides a highly significant new contribution to applied aspects of Georgian grapevine genetic resources management and use. Uniqueness of the Georgian cultivated grapevine gene pool together with its close relatedness with the wild compartment makes this country a good candidate to address questions regarding domestication and grapevine genetic resource conservation. 
Keywords SSRs - Domestication - Molecular fingerprint . Grapevine

\section{Introduction}

Grapevine (Vitis vinifera L.) comprises cultivated ( $V$. vinifera subsp. sativa Beck.) and wild forms ( $V$. vinifera subsp. silvestris Beck.) originally dispersed from western Asia to Europe (Zohary and Horf 2000). Nowadays, more than 6,000 accessions are recorded as individual varieties (Alleweldt and Possingham 1988). The origin of most of them is still questionable or unknown due to (1) existence of several putative domestication centers, dispersed in all the distribution area of the wild progenitor; (2) exchange of plant material among countries; and (3) possible crossing among locally domesticated varieties and grapes imported from abroad.

The South Caucasus (Azerbaijan, Armenia, and Georgia), together with eastern Anatolia, has been considered for a long time as the birth place for viticulture with the earliest examples of winemaking (This et al. 2006; McGovern 2003a, b; Zohary and Horf 2000; Olmo 1995; Levadoux 1956; Negrul 1938; Vavilov 1926). Georgia is considered a cradle for the origin and domestication of cultivated grapevine $V$. vinifera L. subsp. sativa Beck., since many archaeological findings of this region are linked with viticultural and winemaking activities. Historical, ethnographical, religious, and toponimical information give additional argumentations supporting this theory (Hehn 1870; De Candolle 1883; Vavilov 1931; Kighuradze 2000; Ramishvili 2001; McGovern 2003a; Chilashvili 2004; Costantini et al. 2005/2006; Chkhartishvili and Maghradze 2012; Forni 2012; Forni and Failla 2010).

Archaeobotanical and archaeological data, dating back to the sixth and fifth millennium BC (Di Pasquale 2010; Rusishvili 2010; Licheli 2007), support evidence of presence of so-called Shulaveri-Shomu tepe culture (sixth to fourth millennium BC) in the Lower (Kvemo) Katli province of Georgia (sites of Shulaveri, Arukhlo, Khramis Didi Gora, Tsiteli Sopeli, and Kachaghana). Morphological and morphometric characteristics of grape seed remains collected from the site of Shulaveri village (McGovern 2003b) and dated in the sixth to the fifth millennium BC are close to modern cultivated grapevine (Rusishvili 2010; Kokrashvili 2004; Ramishvili 2001). The South Caucasus was covered by the Mtkvari (Kura)-Araks culture from the fourth to the second millennium BC. During the Bronze Age (fourth millennium $\mathrm{BC}$ ), farming in the site of Badaani (Tianeti district of Kartli province) is witnessed by remains of common wheat (Triticum aestivum L. em Thell), Persian wheat (Triticum carthlicum Nev.), multirowed barley, and grapevine seeds (Japaridze and Javakhishvili 1971; Rushishvili 1990; Rusishvili 2010). Other grape seeds were discovered in a settlement of Kvatskhelebi, dating back to 2800 BC (Licheli 2007; Rusishvili 2010).

The Trialeti culture has evolved in the first part of the second millennium $\mathrm{BC}$ and reached its zenith around $1500 \mathrm{BC}$ in Eastern Georgia, evidencing close ties with the highly developed cultures of the ancient world. According to Herodotus (fifth century BC) and Strabon (first century BC), winemaking prospered in Georgia. As also witnessed by: vine stems from Nosiri (Senaki district, second part of the second millennium $\mathrm{BC}$ ), seeds of grapevine from Ergeta (Zugdidi district, seventh to sixth centuries BC), and Gienos (Ochamchire district, seventh to sixth centuries BC), belonging to both subspecies sativa and silvestris (Rushishvili 1990; Rusishvili 2010) as well as grape seeds from Anaklia (Zugdidi district) and Sokhumi (Dzidziguri 1995).

Viticulture and winemaking development continued during the Christian epoch (in Georgia since the fourth century AD). Archaeological findings of many wineries, with wine jars named Kvevri (Kvevri 2011 http://kvevri.org/; Glonti 2010), crushers named Satsnakheli, and other agricultural tools for winemaking and wine care were excavated as well as irrigation systems, terraces for grapevine cultivation, and as reported for previous periods, archaeological seed remains.

Grapevine plants became one of the main ornaments for Christian churches in Georgia. During the Middle Ages, grapevine was considered as a leading crop and winemaking was one of the most important activities (Licheli 2007).

\section{Recent history}

Georgian viticulture and winemaking benefited of the strict link with the development of capitalism in Russia, and new wineries, spirit, and brandy factories were constructed since the second part of the nineteenth century to meet the market demand. In 1879 , the surface dedicated to vineyard reached 70,309 ha.

During the Soviet period, viticulture and winemaking were leading fields in Georgian agricultural activities and in 1973, the vineyard surface was enlarged up to 134,300 ha. Five Georgian local wine cultivars named Rkatsiteli, Saperavi, Tavkveri, Chinuri, and Kakhuri Mtsvane covered $42.7 \%$ of vineyards of the former Soviet Union according to the 1985 census.

\section{Ampelographical platform}

It is not so easy to determine the exact number of autochthonous varieties (both table and wine) for this country. Ampelography of Georgia (Ketskhoveli et al. 1960) reports 525 autochthonous varieties with basic information, while the Ampelography of the Soviet Union (1949-1970) reports ampelographic description of 414 Georgian native varieties. These works together with other local ampelographic books are particularly useful, providing a morphological 
description of the plants and also defining, for the most important Georgian grape varieties, the old putative regions of origin, such as Kakheti, Kartli, Imereti, Racha, Lechkhumi, Samegrelo, Guria, Adjara, Abkhazeti, Saingilo, and Meskheti. At present, the main cultivated varieties in Georgia are autochthonous varieties having high-market value (Census 2004), while the best varieties like Rkatsiteli, Saperavi, Tavkveri, and Mtsvane Kakhuri are also cultivated in East Europe, Middle Asia, and other Caucasian countries.

Awareness of conservation for Georgian V. vinifera germplasm started since the nineteenth century (Staroselski 1893). During the twentieth century many grapevine collections were established in the country (Maghradze 2008). Between 2003 and 2010, significant progress was made in the frame of international research projects on conservation and sustainable use of grapevine ( $V$. vinifera $\mathrm{L}$.) genetic resources in the Caucasus and Northern Black Sea region aiming at strengthening the capacity of the region (Armenia, Azerbaijan, Georgia, Moldova, Russia, and Ukraine) to ensure long-term maintenance of Vitis genetic resources, including the cultivated traditional varieties and the wild gene pool (Bacilieri 2008; Bacilieri et al. 2010; Maghradze and Turok 2012). Beside conservation, the Georgian grapevine germplasm is involved in various scientific programs (Vouillamoz et al. 2006; Imazio et al. 2006; Maghradze et al. 2009a, 2010, 2012; Schaal et al. 2010; Myles et al. 2011).

Wild grapevine $V$. vinifera subsp. silvestris Beck., the wild ancestor of the cultivated grapevine $V$. vinifera subsp. sativa Beck., is a typical representative of the flora of Caucasus and Georgia. This plant is a component of almost all woody regions in Georgia, up to an elevation of 1,200 m (Ramishvili 1988). Nowadays, it grows in sparse small populations or even single individuals. All wild grapevine population suffered important genetic erosion, since the nineteenth century due to human activity expansion, pests, and diseases.

Few medieval references report existence of wild grapevine in this country (Sharden 1711). The first scientific investigation started in the middle of the nineteenth century as witnessed by the work of by Kolenati (1846). In the second half of the twentieth century (1956-1988), Ramishvili (1988) surveyed almost all regions and collected about 400 genotypes organizing them in ex situ field collections. The institute of Horticulture, Viticulture, and Oenology of Tbilisi was recently involved in an inventory, description, investigation and multiplication of wild vines project (Chkhartishvili et al. 2005; Maghradze et al. 2006a, b).

This paper reports the results of a study of genetic diversity and relationships both within the Georgian grapevine germplasm and a selection of representative grapevine varieties distributed worldwide using nuclear microsatellite markers. The advent of molecular markers offers a powerful tool to address these issues, as it was shown by previous works on grapes (Aradhya et al. 2003; Laucou et al. 2011) or other plant species (Harter et al. 2004; Vigouroux et al. 2005; Hamblin et al. 2007). Among these, SSR is the most prevalently utilized for genotyping individuals; solving problems of homonymy, synonymy, and kinship; and inferring the genetic structure of populations (Sefc et al. 2000; Grassi et al. 2003a; Cipriani et al. 2010).

To carry out precise and unbiased structure and parentage analysis, a set of 20 markers in linkage equilibrium was defined, selecting at least one locus per chromosome (Doligez et al. 2006). To be able to compare the local germplasm with a larger reference, we choose the same set that Laucou et al. (2011) used to characterize 2,323 different cultivars of the Vassal collection (http://www1.montpellier.inra.fr/vassal/, INRA France).

By combining historical and molecular approaches, checking whether local genetic groupings are concordant with the known history of the cultivars as well as their relations with the viticulture world, this paper aims to contribute to a better definition of the role played by Georgia in grapevine domestication and to contribute to an efficient preservation of old local genotypes that could represent valuable genetic combinations for a new and renewed viticulture.

\section{Materials and methods}

Plant materials

\section{Cultivated accessions}

One hundred twelve cultivated varieties were selected basing on previous works (Maghradze et al. 2009a, b) as representatives of Georgian native grapevine germplasm. All accessions are maintained in a grape germplasm repository in Gorizia province (Friuli-Venezia Giulia region, Italy) and 22 identified Georgian varieties are also available in the Institut National de la Recherche Agronomique (INRA) grape germplasm repository of Domaine de Vassal. The sample set is representative of $21 \%$ of the total amount of traditional Georgian grape varieties (according to the already mentioned Georgian and Russian ampelography). Thus, it can't be considered exhaustive but most Georgian varieties, even the ones present in germplasm collections, lack complete ampelographic and molecular characterization and for this reason, only the true to type varieties were considered in this work.

\section{Wild accessions}

Eighteen true wild grapevines were also included in the analysis. All of them were selected in the spontaneous flora. 
The main problem in sampling of wild $V$. silvestris grapevines is avoidance of false attribution to this subgroup of interspecific hybrids ( $V$. vinifera $\times$ Vitis species) or feral $V$. vinifera accessions that escaped from cultivation. To avoid this kind of mistakes, the area of sampling should be far from vineyards (even abandoned ones) and plants should be checked for typical morphological characteristics such as leaf, berry, and seed dimension and shape, which differentiate the two subspecies (Anzani et al. 1990; Grassi et al. 2003b). According to the principles defined in the frame of the European GrapeGen06 project (http://www1.montpellier.inra.fr/grapegen06/ accueil.php), the distances between wild accessions and cultivated vineyards were taken into account, and in the definition of each site of collection, a minimum distance of $10 \mathrm{~km}$ was considered. This measure was decided considering that the $V$. vinifera pollen grain of medium weight is not able to cover very long distances (Arnold 2002). To avoid the risk of collecting interspecific hybrids, differentiation between real wild vines and exotic ones from North America was carried out observing the main ampelographical descriptors and schemes on leaf and flower (Larrea 1978; Ocete et al. 2006); in addition, the SSR fingerprints were compared with the same data performed in other Vitis species. The 18 wild accessions were compared with a total of 53 samples belonging to different Vitis species conserved in the Vassal Germplasm collection and no match was found, neither identities nor kin. The most interesting and distinctive character is the flower structure: wild grapevines are dioecious while cultivated varieties are, in general, hermaphrodites. All wild samples were vegetatively propagated and are under cultivation in pots at the Milano University greenhouse facilities to allow continued morphological survey and characterization. This was particularly useful to define sex of wild samples (which is not always detectable in the wild) and allowed to calculate sex ratio. Sex attribution as well as other characteristics for wild and cultivated accessions is reported in Online resource 1a. In addition, few information regarding ecology of silvestris collection sites is given in Online resource $1 \mathrm{~b}$.

\section{SSR genotyping}

Samples of young leaves were collected for each accession during the active growing seasons in the field collection or from rooted woody cuttings in the greenhouse. DNA was extracted using Qiagen DNeasy Plant commercial kit. Twenty nuclear SSR loci were selected for their quality, polymorphism, and distribution across the 19 grapevine chromosomes based on the work of Doligez et al. (2006). These loci were detected on an automated ABI PRISM ${ }^{\circledR}$ 310 Genetic Analyzer (Applied Biosystems, Life Technologies, Foster City, CA, USA). Alleles were scored using GeneMapper 3.10 (Applied Biosystems, Life Technologies) and allele sizes were recorded in base pair with two decimal precision. After binning of alleles with
Microsoft Excel, allele sizes were standardized to the sizes of reference varieties so the comparison could be made among collection datasets.

\section{Data analysis}

Diversity analyses were performed using the software GenAlEx (Peakall and Smouse 2006) to estimate, once redundant genotypes were excluded, the average number of observed alleles per locus $(\mathrm{Na})$, the inbreeding coefficients (Fis), the observed heterozygosity (Ho), the average gene diversity and expected heterozygosity $(\mathrm{He})$. The software IDENTITY 1.0 (Wagner and Sefc 1999) was used to estimate the frequency of null alleles $(r)$ and the probability of identity (PI).

Genetic differentiation among groups of individuals was estimated by hierarchical analysis of molecular variance (AMOVA) basing on Fst values computed for our codominant data. F-statistics (Cockerham and Weir 1983) was performed with 100,000 permutations.

To describe the structure of these samples, a distance matrix based on Nei's GD was processed to obtain a neighbor-joining tree by PHYLIP package (Felsenstein 1989) and the dendrogram was displayed with TreeView 1.6.6. To visualize the genetic distances between accessions, PCA was carried out based on the matrix of genetic distance for codominant data (Smouse and Peakall 1999) and using GenAlEx software. Relationships between distance matrix elements were plotted based on their first two principal components.

Comparison between Georgian and Vassal collection grapevine samples This part of the work was devoted to the comprehension or the role played by Georgian viticulture in the definition of ampelographical platforms of different European countries. The Vassal grapevine repository was selected as representative of the worldwide grape cultivated varieties.

First of all, we were interested in evaluating if the 20 SSR loci were represented in the same way in samples from Georgia (sativa and silvestris) and other countries; for this reason, we compared the allele frequencies obtained in both cases and we performed a $\chi^{2}$ test that we used to draw a tree linking together groups of accessions based on allele frequencies. Allele frequencies were also used to perform a PCA giving a spatial representation of distances among the four groups. Genetic distances among grapevines from Georgia and other countries were calculated using the Nei's index (1978) and a neighbor-joining tree was drawn in the same fashion previously described.

Finally, a parentage analysis was carried out, with the FaMoz software (Gerber et al. 2003) adapted to grape (Di Vecchi Staraz et al. 2007) to verify possible genetic relationships (parent-offspring (PO), half or full siblings) among 
the Georgian group of sampled varieties and the entire Vassal collection. A discrepancy of two loci was fixed to allow possible mistakes (Hoffman et al. 2005), the presence of null alleles (Dakin and Avise 2004; Wagner et al. 2006), or mutations (Riaz et al. 2002). The effect of scoring errors was also taken into account, searching relationships including possible mismatches (or incompatibilities) on a maximum of two loci, performed with FaMoz mistyping of $10^{-7}$ likelihood ratio, with a set of 20 markers.

The software method involves calculation of the logarithm of the likelihood ratio, log of odds ratio (LOD score), by determining the likelihood of an individual (or pair of individuals) being the parent (or parents) of a given offspring divided by the likelihood of these individuals being unrelated. LOD scores for any potential parentage relationship (parent/parent pair) with a value greater than zero are computed, giving statistical significance to the data.

Possible parents determined by logarithm of odds (LOD) scores and significance thresholds were probed among the 2,323 cultivars characterized with the set of 20 SSR markers (Laucou et al. 2011). Di Vecchi Staraz et al. (2007) determined, through 100,000 simulated parent pairs, a LOD score threshold of 8 for assessing a potential parent pair with 20 SSRs. Based on this, only pairs with LOD scores $>8$ were considered as valid in our work.

Uniparental most likely relationships are presented (relationship including only one parent and based on the fact that both individuals share at least one allele at each locus) with a likelihood ratio of the potential relationship. Most likely parent pairs are also displayed with the LOD scores.

\section{Results}

Genetic structure of Georgian germplasm (cultivated and wild accessions)

The 130 Georgian accessions were genotyped with $20 \mathrm{nu}-$ clear SSRs loci and inserted in the European Vitis Database. All the samples were collected in the same germplasm collection, but due to the existence of several common accessions (22) in the Vassal repository, a screening was made to verify the fingerprints. Each accession was represented by a single variety, with the exception of Badagi and Djineschi that were represented by two accessions both collected in Gorizia but coming from two different Georgian germplasm collections. In both cases, the two accessions were not coincident and we were able to select a putative true to type of Badagi comparing it with the Badagi accession present in the Vassal repository. In the case of Djineschi, this was not possible and both the accessions are marked not being true to types.
Allele frequency, observed heterozygosity, expected heterozygosity $(\mathrm{He})$ or Nei's gene diversity, the fixation index (Fis) or inbreeding coefficient, null alleles frequencies $(r)$, and probability of identity (PI) were calculated locus by locus and presented in Online resource 2. The average number of alleles per locus $(\mathrm{Na})$ was higher in the cultivated dataset than in the wild one (14.450 vs. 8.750). However, the increase in allele numbers in the cultivated and wild samples did not significantly increase their effective allele number $(\mathrm{Ne})$ that was quite similar in both cases. While the allele number largely depends on the complexity and size of the germplasm sampled, the effective number identifies those alleles occurring at a relevant frequency within the sample. In agreement with the results of allelic diversity, the expected heterozygosity or gene diversity $(\mathrm{He})$ was also very similar in both groups, while the observed heterozygosity (Ho) was slightly lower for the cultivated samples than for the wild samples.

Figure 1 gives a graphical representation of the allelic patterns across the cultivated and silvestris groups. The inbreeding coefficient (Fis) was estimated at each locus; negative values were scored for eight out of the 20 SSR markers in the cultivated compartment and for 11 in the silvestris subset. The Fis values calculated for each locus indicate the absence of inbreeding or undetected null alleles affecting Georgian grape germplasm. The mean Fis values over loci for each compartment and for the total dataset were very close and not significantly different from 0 .

Genetic differentiation among cultivated and wild compartments was estimated by hierarchical AMOVA. Results suggest that the largest part of differentiation has to be attributed to differences within the groups, both when considering the two subspecies (Fig. 2a) and also when splitting the cultivated compartment in eight different areas of traditional cultivation (Fig. 2b), while only 6 to $10 \%$ of variation is due to variability among groups and among different geographical locations.

To verify the consistency of the gene flow from the Georgian silvestris compartment to the sativa vines, a population pairwise Fst estimate was computed (Table 1) and the resulting values were compared with the ones obtained in other recent works regarding grapevine domestication and gene flow between the two subspecies (Zinelabidine et al. 2010; Myles et al. 2011; De Andrés et al. 2012). On the other side, to visualize the genetic distances between accessions, PCA was computed based on the matrix of genetic distance for codominant data. The relationships between genotypes were plotted basing on their first two principal components (Fig. 3), accounting for $48.21 \%$ of total variability, and different subsets were differentiated by both principal components. To verify the existence of a relationship among accessions and different regions of the country, Nei's genetic distances were computed among the nine 
Fig. 1 Allelic patterns across the two groups. $N a$ number of alleles detected, $N a>5 \%$ number of alleles with frequency higher than $0.5, \mathrm{Ne}$ number of effective alleles, $I$ Shannon information index

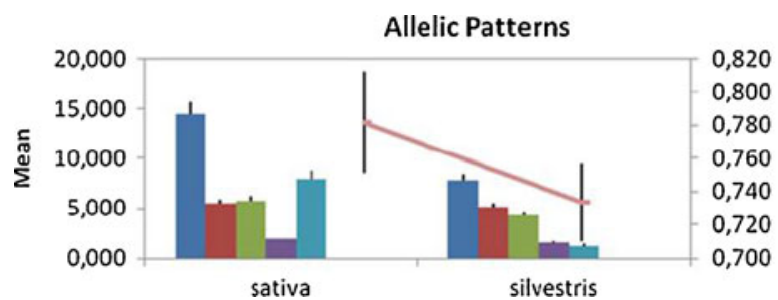

groups of accessions according to their major cultivation area. A neighbor-joining dendrogram, based on Nei's genetic distance, was built to give a graphical representation of the genetic distances among groups and to compare it to geographical ones (Fig. 4).

Parentage analysis and comparison with Vassal repository accessions

The allele frequencies obtained in Georgian sativa and silvestris groups were analyzed in comparison with the results discussed by Laucou et al. (2011), since this work examined 2,323 cultivars of the Vassal repository collection genotyped using the same 20 nuclear SSR. The $\chi^{2}$ distance

\section{Percentages of Molecular Variance}

(a)

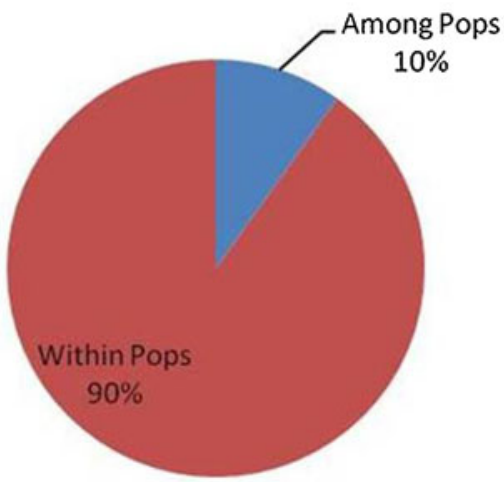

Percentages of Molecular Variance

(b)

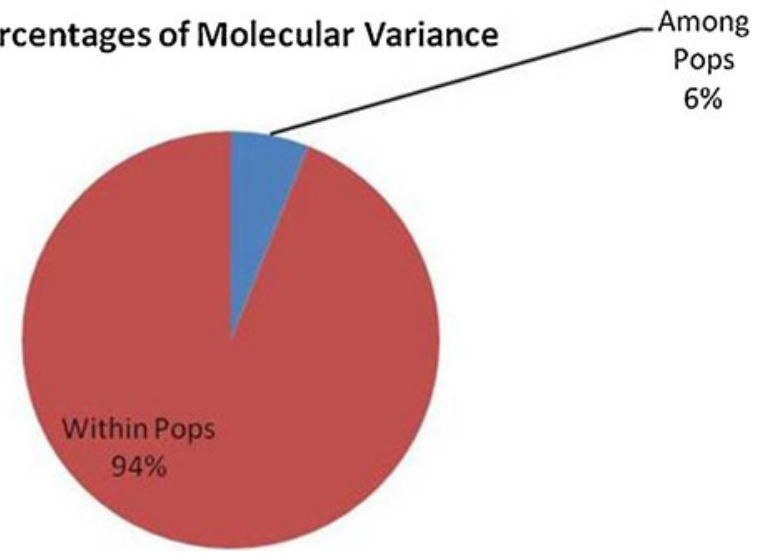

Fig. 2 a, b Analysis of molecular variance: defined with two populations (silvestris and sativa) (a) and among nine pops (silvestris and the cultivated accessions distributed in their eight proveniance regions) (b) test was applied on allele frequencies to verify the distances among the groups. A dendrogram drawn based on the results of the $\chi^{2}$ test among the four groups (Georgian: cultivated and wild; Vassal cultivated and wild) is proposed in Fig. 5. Based on allele frequencies, a PCA analysis was computed, and the coefficients for each allele at each SSR loci, describing the PCA representation shown in Fig. 6, are reported in the last three columns of Online resource 3.

To verify the link and possible relationships among Georgian cultivated grapevines and other foreign varieties, the Nei's genetic diversity was calculated in a dataset obtained combining SSR data for Georgian cultivated varieties and all the sativa samples inserted in the Vassal repository. A Ward (Ward 1963) dendogram was drawn and presented in Fig. 7 Finally, a likelihood-based approach was used to detect and explore most likely PO relationships among the Vassal repository samples and the Georgian accessions sampled for this work.

\section{Discussion}

Georgian germplasm structure and conservation

Number of alleles detected, observed, and expected heterozygosity for each loci were almost comparable with the ones evidenced in previous works devoted to the study of traditional grapevine cultivars from the South Caucasus and Anatolia (Vouillamoz et al. 2006; Maghradze et al. 2009a, b; Frare et al. 2011) and are in general agreement with the ones detected in cultivated and wild grapevine (Aradhya et al. 2003; Ibàňes et al. 2003; Sefc et al. 2003; Hvarleva et al. 2004; Zinelabidine et al. 2010; De Andrés et al. 2012). Number of alleles, varying from four to 27 , respectively, at VVIn16 and VMC4f3 in our analyses, turned out to be comparable with the number of alleles and loci performed in the work of Laucou et al. (2011) on 2,323 cultivars. The mean value of expected heterozygosity $(\mathrm{He})$ was of $0.786 \pm$ 0.031 for the cultivated compartment and of $0.777 \pm 0.023$ for the silvestris group. The cultivated value was comparable with the one detected in the work of Laucou et al. (2011) for cultivated samples $(0.76 \pm 0.12)$, while the wild samples detected in the previously cited work performed a lower value $(0.62 \pm 0.13)$. This result was quite unexpected, considering the higher number of silvestris (72 genotypes with 
Table 1 Pairwise population Fst values

\begin{tabular}{|c|c|c|c|c|c|c|c|c|c|}
\hline & Abkhazeti & Adjara & Silvestris & Guria & Imereti & Kakheti & Kartli & Ratcha-Letchumi & Samegrelo \\
\hline Abkhazeti & 0.000 & & & & & & & & \\
\hline Adjara & 0.046 & 0.000 & & & & & & & \\
\hline Silvestris & 0.076 & 0.069 & 0.000 & & & & & & \\
\hline Guria & 0.061 & 0.058 & 0.078 & 0.000 & & & & & \\
\hline Imereti & 0.051 & 0.039 & 0.042 & 0.045 & 0.000 & & & & \\
\hline Kakheti & 0.061 & 0.046 & 0.056 & 0.074 & 0.028 & 0.000 & & & \\
\hline Kartli & 0.069 & 0.047 & 0.055 & 0.080 & 0.031 & 0.017 & 0.000 & & \\
\hline Ratcha-Letchumi & 0.072 & 0.046 & 0.055 & 0.073 & 0.035 & 0.034 & 0.033 & 0.000 & \\
\hline \multirow[t]{2}{*}{ Samegrelo } & 0.047 & 0.046 & 0.060 & 0.049 & 0.033 & 0.035 & 0042 & 0.047 & 0.000 \\
\hline & Sativa & Silvestris & & & & & & & \\
\hline Sativa & 0.000 & & & & & & & & \\
\hline Silvestris & 0.039 & 0.000 & & & & & & & \\
\hline
\end{tabular}

single profiles among 80 analyzed) samples present in the Vassal repository compared with the 18 Georgian and also considering that wild accessions present in the French germplasm collection have different proveniences while the samples analyzed here all belong to the same local flora and places of sampling in the wild are not far the ones from the others. Moreover, the significant reduction of Ho, compared to $\mathrm{He}$, usually experienced in Western European silvestris populations (Grassi et al. 2003b; Di Vecchi et al. 2006; Cunha et al. 2007; Lopes et al. 2009; Zecca et al. 2010; Zinelabidine et al. 2010; De Andrés et al. 2012) is not confirmed in the case of Georgian wild populations and individuals. These data are interesting because they indicate that Georgian cultivated and wild germplasm, despite isolation and low material exchange occurring during the past centuries, maintain a high level of gene diversity. This result

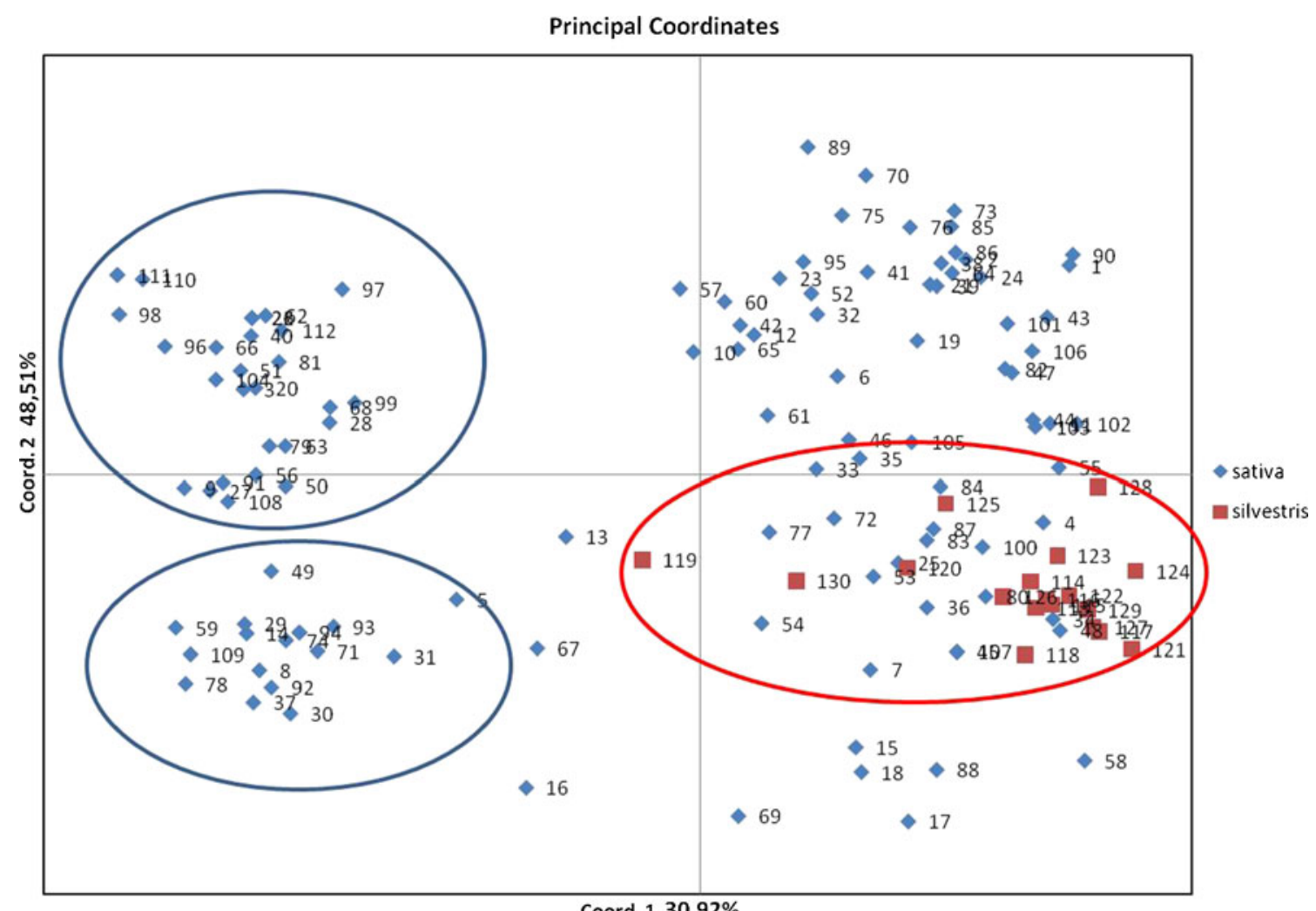

Fig. 3 Principal component analysis performed on Georgian samples (silvestris and sativa). Red circle evidences silvestris samples, while blue circles group samples that seem to cluster basing on their geographical proveniance 

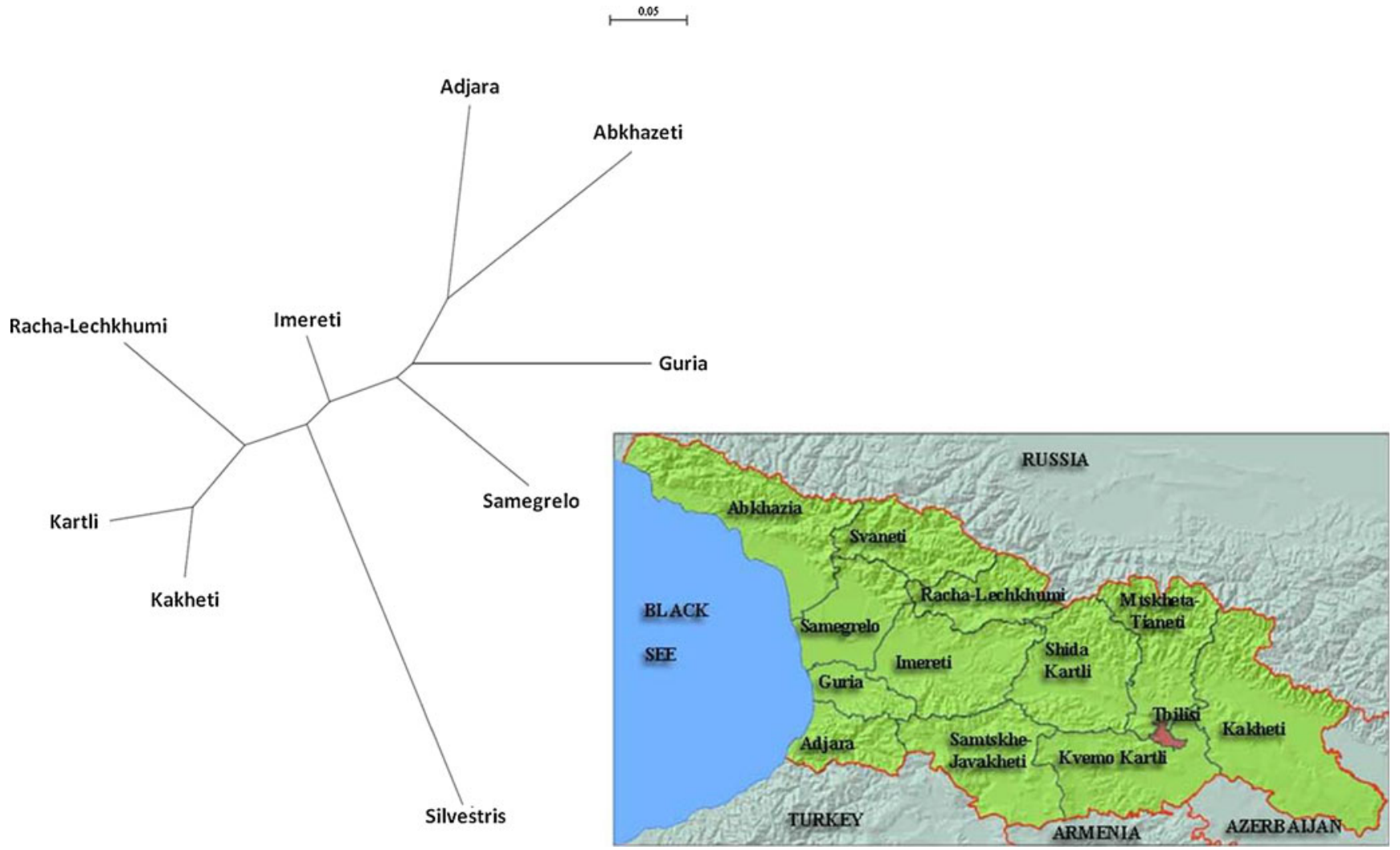

Fig. 4 Neighbor-joining tree computed on a Nei's genetic distance matrix and map of Georgia evidencing regions

is probably related to the long-standing cultivation tradition in Georgia (McGovern 2003a, b) but, first of all, it evidences the genetic richness contained in the wild silvestris compart- ment, underlining their good state of health.

The use of common loci was also useful in performing a locus by locus comparison of alleles detected in the datasets
Fig. 5 Dendrogram drawn basing on the results of the $\chi^{2}$ test among the four groups (Georgian: cultivated and wild; Vassal cultivated and wild)

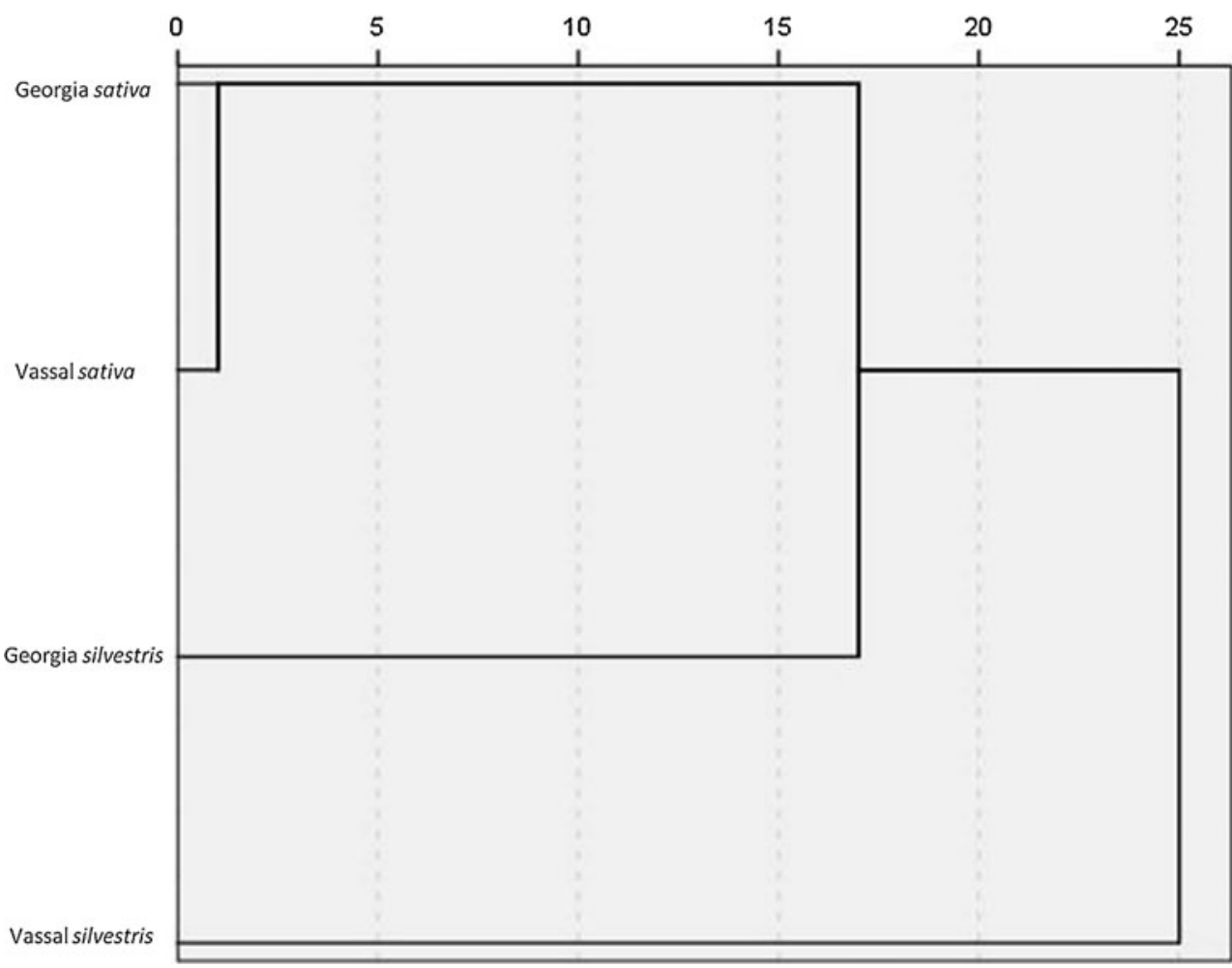


Fig. 6 PCA analysis was computed basing on allele frequencies. The eigenvalues for each allele at each SSR loci, describing the PCA, are reported in the last three columns of Electronic Supplemental Material 4

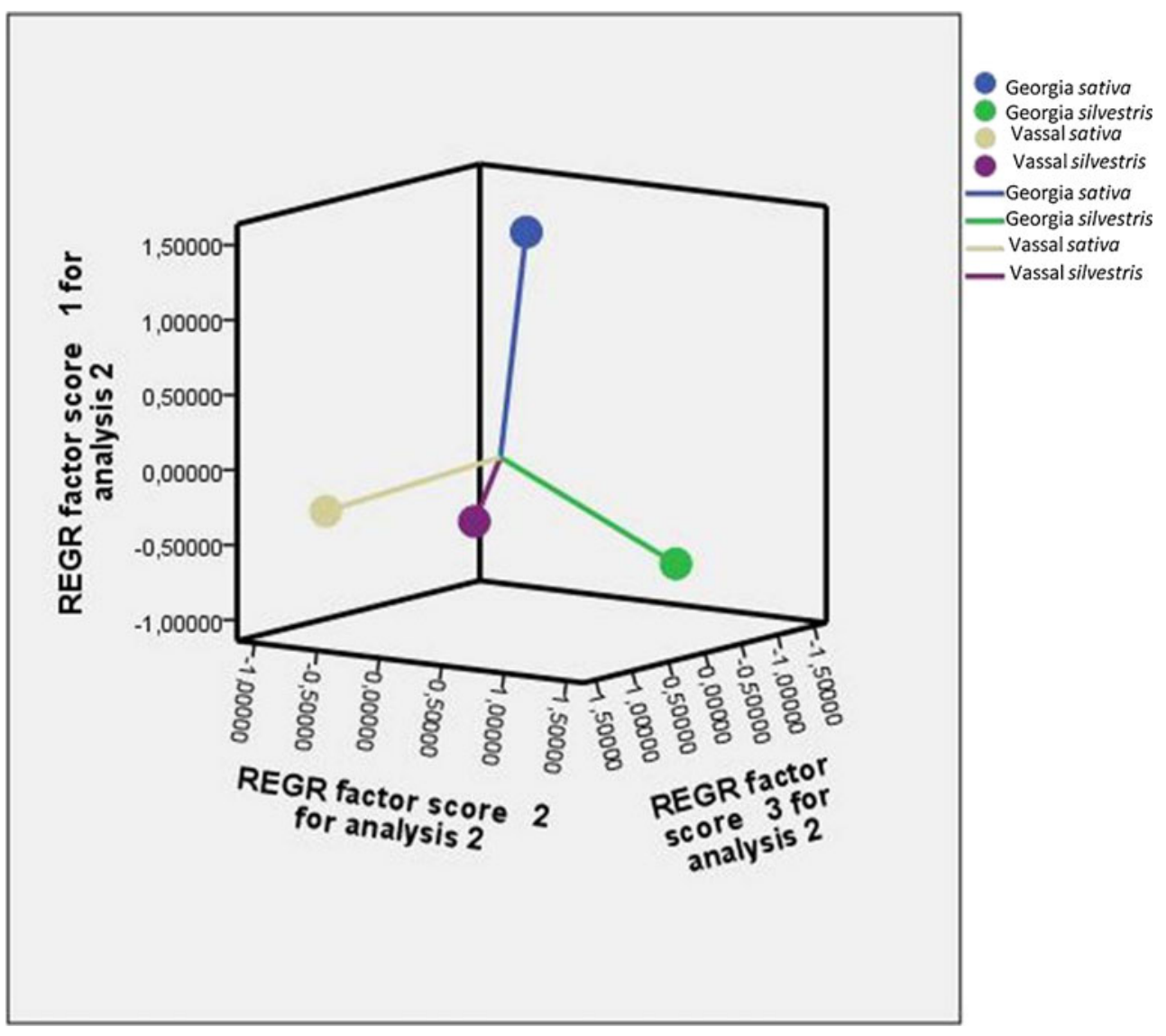

(Vassal and Georgia) and of their allele frequencies. The majority of allele frequencies (in all loci) from Georgian accessions were mainly coincident with the ones obtained in the Vassal repository (Online resource 3).

Among the alleles with different frequencies, overall loci, we were particularly mindful to those well represented in the Georgian dataset (sativa and silvestris) and absent or poorly represented in all the $V$. vinifera silvestris compartment described in Vassal, thus representing the wild $V$. vinifera populations collected worldwide. Among the 316 alleles identified in the 130 Georgian cultivars and in the 2,323 Vassal accessions, 73 alleles were presented in Georgian cultivars (with a frequency from 0.0044 to 0.1157 ) and not presented in Vassal accessions; just 15 alleles were present in the Vassal genotypes (with a frequency ranging from 0.0002 to 0.1048 ) and absent in the Georgian varieties. On the silvestris side, 59 alleles were present in the Georgian wild vines (frequency from 0.0217 to 0.5 ) and absent in Vassal wild vines, while the unique alleles were 48 (harboring a frequency range $0.0005-0.5347$ ). These cases were present also in the most highly polymorphic SSR loci, thus reducing the risk of making erroneous suppositions based on a low number of alleles. The presence/absence of nuclear and chloroplast SSR alleles and the comparison of allele frequencies among countries have already been useful in the definition of the genetic structure of ampelographic
European country platforms (Arroyo-García et al. 2006; Imazio et al. 2006). Studies on the Georgian viticulture seem to confirm, on one hand, the genetic richness of this viticulture and the originality of traits probably linked to local domestication events and on the other hand, the existence of the same alleles also in the cultivated compartment collected elsewhere and the contemporary absence in the wild dataset from the same countries could be considered a clue confirming the important role played by Georgian $V$. vinifera even in the formation of foreign varieties.

The detected allele frequencies for each of the four groups (wild and cultivated accessions from Georgia and Vassal) were used to perform a $\chi^{2}$ distance test among the groups and to draw a dendrogram (Fig. 5), evidencing that the Georgian silvestris compartment is much closer to the cultivated varieties (Georgia and worldwide) than the Vassal silvestris is.

This last observation finds a confirmation in the recently published work of Myles et al. (2011), where a 9,000 high quality SNP array (Vitis 9k SNP array) was used to genotype 1,000 samples of $V$. vinifera. In this work, authors state that the haplotype diversity in western samples was slightly reduced compared with the eastern vinifera, and the population pairwise Fst estimates confirmed that all vinifera groups, considered in that work, were genetically closer to eastern silvestris than to the western one. Due to the absence of Georgian samples (no cultivated accessions 


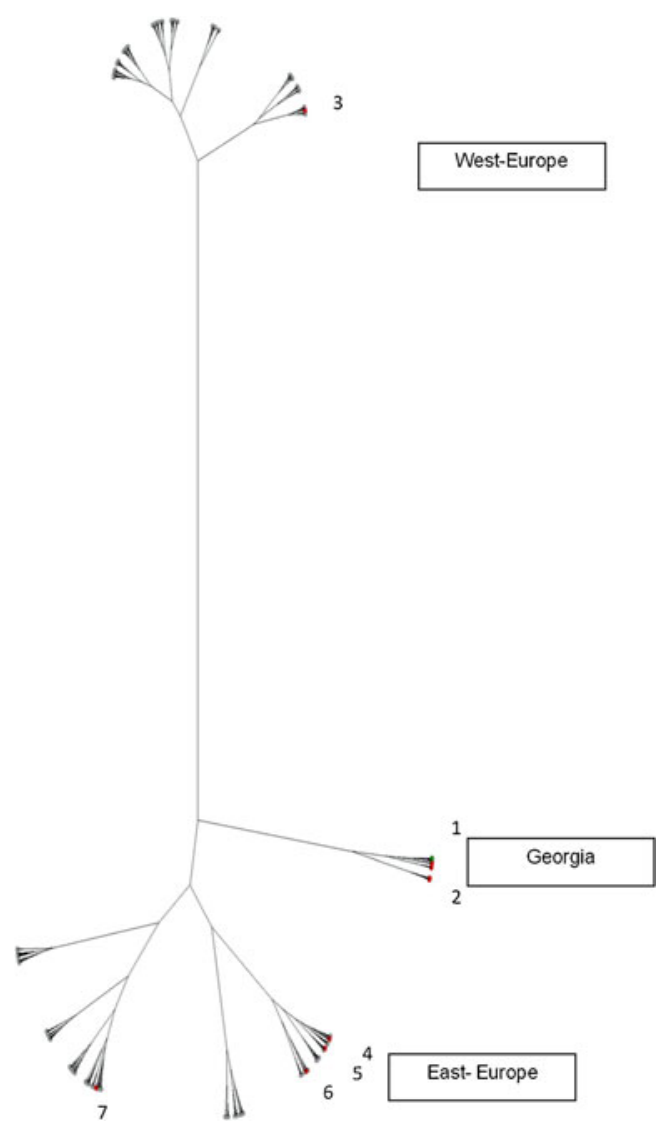

Fig. 7 Dendrogram based on the Ward method of hierarchical clustering, maximizing the between-group variance. It describes the distance dividing Georgian viticulture from other countries' grapevine platforms. In green (1), positions of the 23 Georgian wild grapevines, all grouping together. In red, the positions of the cultivated Georgian grapevines: (2) a group of 106 Georgian cultivated grapevines, grouping together; (3) a cultivar (Tsulukidzis tetra) close to Gouais or to Heunisch, and 4 to 7 Georgian cultivars grouping with cultivars from other East European regions [4 Tsnoris tetra, 5 Dzveli Aleksandrouli, 6 Djvari, 7 Saperavi, and Dzelshavi obchuri]

and only five wild samples were included) in that work, our results on Georgian wild and cultivated grapevines integrate the information given by Myles et al. (2011) and partially confirm their conclusions on the role of the Near East in grapevine domestication.

To verify in detail the role played by silvestris compartment in the constitution of the cultivated grapevine Georgian platform, we computed Fst population pairwise estimations (Table 1) both considering vinifera and silvestris as two separate groups and further splitting the sativa in eight different regional subgroups based on putative geographical provenience or the most prevalent growing area of each accession. Results evidenced lower values of Fst than the ones showed in previously published works (Zinelabidine et al. 2010; Myles et al. 2011; De Andrés et al. 2012) confirming a close relationship between silvestris and sativa individuals within Georgia. More details about this link were obtained by PCA presented in Fig. 3. Interestingly, the PC2 combined with low values of PC1 identified a differentiation in the sativa compartment and the individuals inserted in the two blocks are thought to belong to different geographical areas; the plants putatively originated in the eastern regions (Kartli, Kakheti) differ from the ones originating from the western part of the country (Abkhazeti, Samegrelo, Racha-Lechkhumi, Guria, and Adjara). This subdivision seems to reflect the geographical barrier constituted by Likhi Mountains connecting Major and Minor Caucasus, thus running in a north to south direction across Georgia and dividing the territory into two mayor parts. Remarkably, ampelographical characteristics, as leaf hairiness, seem to present differences among east and west varieties (Negrul 1946; Tsertsvadze 1989). The maintenance of phenotype and genotype differences, still able to distinguish the varieties based on their putative initial place of origin, is another confirmation that despite long-standing cultivation, traditional Georgian grapevines maintain their originality and local link to their main growing region.

On the other side, the first component of the PCA analysis defines two other groups (left and right hand sides of the graph). Interestingly, the group characterized by high levels of the second component comprises cultivated samples and silvestris accessions; thus, in the Georgian dataset, we are not able to clearly differentiate and separate silvestris and sativa compartments. Indeed, wild accessions are well distinguished from a part of the cultivated ones, but they are also completely overlapping with another subset of sativa accessions. The low Fst value (0.039) between Georgian sativa and silvestris groups finds here a graphical representation of the admixture existing between the two subgroups. Based on these considerations, two scenarios could be defined: the presence of "intermediate" cultivated genotypes may be explained by the presence of a gene flow between V.v. sativa and V.v silvestris (these genotypes being, thus, either first degree crossbreds or complex backcrosses) or, alternatively, by the hypothesis that the cultivated grapevine was derived through "domestication" by some genotypes and not others, thus implying that $V$. v. silvestris populations may not be homogeneous but rather contain at least two types of genotypes and just one was collected and analyzed in this work, the other one becoming extinct or simply not considered in this frame. We must report that Georgian ampelography is rich in cultivated varieties which names recall wild conditions, such as Tkis Vazi from Kakheti (East Georgia) and Tkis Kurdzeni from Adjara (West Georgia) where Tkis means forest, or bearing ampelographic traits (grapes and leaves) rather similar to wild vines, such as Tagidzura, Shavkurdzena, Opoura, Tchodi, Tsvrimala, Chitistvala Adjaruli, and Chrogha Kakhetis cultivars.

The positioning of silvestris genotypes in the PCA seems also to confirm, once again, the absence of interspecific 
hybrids among the wild samples collected. In fact, on the opposite, we should be able to identify silvestris samples isolated from the $V$. vinifera compartments, which is not. The neighbor-joining tree built upon Nei's genetic distance, among the nine data subsets confirmed the picture drawn by the Fst analysis. Moreover, results represented in Fig. 4 clearly show that genetic distances are directly proportional to regional distances: Kakheti and Kartli are two neighboring provinces in East Georgia, while Imereti, Samegrelo, Guria, Abkhazeti, and Adjara are neighboring regions of West Georgia. Georgia silvestris accessions included in this study were collected from East Georgia and, as expected, they have more similarities with the Eastern Georgia regions (Fig. 4).

All the considerations made above seem to underline the importance of the Georgian viticulture. First of all, the analyses accounted for high genetic diversity and variability. A quite unexpected result concerned the correlation of the genetic structure of Georgian germplasm with geographic locations, pointing to low germplasm and variety exchanges among regions and to the conservation of selected varieties in the regions. Our results seem to describe a scenario where grapevine cultivation has very old and strong cultural tradition and domestication seems to have occurred in different places in the frame of the country. All witnessed by the genetic richness still harbored in the cultivated varieties. To better investigate and comprehend the uniqueness of Georgian viticulture and to add information to the knowledge acquired on varietal circulation in the past, a comparison with cultivars from other countries was made, searching for contact points such as PO relationships and other clues, allowing detection of varietal exchange and admixture.

Parentage analysis and comparison with Vassal repository accessions

In spite of the distance, during all its history, Georgia kept relationships with European countries and peoples. Greek and Hellenistic colonies, documented on the Black Sea coasts of Georgia, played an important role in trades and cultural exchanges during the sixth to first centuries BC (Lomouri 1962; Lortkipanidze 1980); the Roman Empire was present in the Kartli region and in Colchis till the fourth century AD. The Byzantine Empire was a Georgia neighbor during the fourth to fifteenth centuries AD. Genoa Republic colonies on the Black Sea during the thirteenth to fifteenth centuries AD (Genoa 1979) and the Vatican catholic missioners in Georgia during the thirteenth to nineteenth centuries AD (Catholicism 1980) are documented as well. Furthermore, Georgia is strategically located: on the crossroad from Europe to Asia, between the Black and Caspian seas on the main trading roads, along the Great Silk Road (from the second century BC to the seventeenth century AD).
All these considerations increased curiosity in verifying the consistency of the putative role played by Georgian grapevines in the definition of the international grapevine platforms distributed worldwide.

First of all, the genetic distances with Vassal individuals were calculated (Nei 1978). This led to the tree represented in Fig. 7, where most of the Georgian accessions define a branch apart with apparently no admixture with other varieties belonging to other countries. Another interesting aspect of the scenario described in the dendrogram is that genetic distances seem to reflect geographical distances among countries, confirming once again that despite the knowledge about the existence of few primary domestication centers for grape, quite surely, local domestication events occurred at different times during grapevine history and evolution, and modern molecular genotyping techniques proved that they were of great importance in the definition of the actual genetic structure.

To better investigate these points, the FaMoz software, devoted to the reconstruction of pedigrees from molecular data such as codominantly inherited SSR markers, was used. The FaMoz software highlighted genetic relationships linking Georgian varieties. This data combined with ampelographic characterization and historical records should be used for cultivar classification. However, this ample target is out of the mission of the present article and the details will not be presented here. We also underline that the 20 SSR used in this work, even if they are uniformly distributed in the genome, are not enough to correctly attribute PO relationships, but the aim of this work was principally to elucidate the degree of admixture between viticulture of Georgia and other countries. Most of the relationships scored involved: Georgian material (data not shown) and Georgian accessions and varieties belonging to near or neighboring countries (such as Azerbaijan, Armenia, Russia, Iran, Ukraine, and Syria) and few interesting cases involving Georgian material and other European accessions as shown in Table 2. This result is not surprising, and these varieties could be particularly interesting in the frame of investigating grapevine domestication due to the fact that all the cited nations are considered putative areas of origin for grapevine cultivated varieties and could be interesting materials to address further investigations regarding genetic traits putatively selected through domestication such as berry pigmentation (Azuma et al. 2008; Lijavetzky et al. 2006) and aroma (Emanuelli et al. 2010). Other foreign countries involved in eventual PO relationships are France, Italy, Greece, and Austria. The most interesting aspect on this side is to define, when possible, the direction of these relationships; comprehending if the Georgian varieties involved are real autochthons of this country or if they have to be considered as introductions from abroad. Helpful, under this point of view, is the history of each variety combined with genetic information derived from the 
Table 2 Principal PO relationships identified between Georgian cultivated varieties and accessions present in the Vassal Repository and likelihood values (Only relationships with a LOD score $>8$ were considered)

\begin{tabular}{|c|c|c|}
\hline Georgian variety & putative PO relationships (single parent) & LOD SCORE \\
\hline ASURETULI SHAVI & RHODITIS (GREECE) & 14.31 \\
\hline BUERA & GANZIANDY (ARMENIE) & 33.75 \\
\hline DJVARI & MEHDIK (IRAN) & 15.95 \\
\hline GOMIS TETRI & GANZIANDY (ARMENIE) & 23.05 \\
\hline KAKHIS TETRA & PROSECCO TONDO (ITALY) & 10.29 \\
\hline KHARISTVALA KOLKHURI & DURIF (FRANCE) & 8.58 \\
\hline KHIKHVI & GANZIANDY (ARMENIE) & 08.23 \\
\hline MAGHLARI SHAVI & ASSYLKARA (DAGESTAN - RUSSIA) & 9.93 \\
\hline MARGULI SAPERE & ASSYLKARA (DAGESTAN - RUSSIA) & 22.30 \\
\hline MARGULI SAPERE & BEKALNY (RUSSIA) & 16.27 \\
\hline MSKHVILTVALA TETRI & GANZIANDY (ARMENIE) & 8.87 \\
\hline PORTOKA & DURIF (FRANCE) & 18.59 \\
\hline PORTOKA & SYRAH (FRANCE) & 8.74 \\
\hline TSULUKIDZIS TETRA & PICCOLA NERA (ITALY) & 15.83 \\
\hline TSULUKIDZIS TETRA & MEHLWEISS (AUSTRIA) & 14.12 \\
\hline TSULUKIDZIS TETRA & GUEUCHE BLANC (AUSTRIA) & 11.89 \\
\hline Georgian variety & putative PO relationships (parent couple) & LOD SCORE \\
\hline ASURETULI SHAVI & RHODITIS (GREECE)XMAUVROUIDON (GREECE) & 13.41 \\
\hline ASURETULI SHAVI & RHODITIS (GREECE)XKOTSIPHALI (GREECE) & 11.66 \\
\hline BZVANURA & GANZIANDY (ARMENIE)XCHKHUTCHESHI (GEORGIA) & 30.11 \\
\hline BZVANURA & DELI KAPTAR (TAJIKISTAN)XCHKHUTCHESHI (GEORGIA) & 29.16 \\
\hline DJVARI & MEHDIK (IRAN)XMTSVANE KAKHURI (GEORGIA) & 29.14 \\
\hline DJVARI & MEHDIK (IRAN)XRKATSITELI (GEORGIA) & 23.95 \\
\hline DZIGANIDZIS SHAVI & MAGHLARI TVRINA (GEORGIA)XPETIT VERDOT (FRANCE) & 16.68 \\
\hline GOMIS TETRI & GANZIANDY (ARMENIE)XBUERA (GEORGIA) & 29.34 \\
\hline KAKIS TETRA & PROSECCO TONDO (ITALY)XKAISI BALADI (SYRIA) & 12.35 \\
\hline PORTOKA & DURIF (FRANCE)XVIOGNIER (FRANCE) & 17.85 \\
\hline PORTOKA & SYRAH (FRANCE)XDURIF (FRANCE) & 10.13 \\
\hline TSULUKIDZIS TETRA & BLANK BLAU (AUSTRIA)XGUEUCHE BLANC (AUSTRIA) & 23.01 \\
\hline TSULUKIDZIS TETRA & MEHLWEISS (AUSTRIA)XPICCOLA NERA (ITALY) & 21.76 \\
\hline TSULUKIDZIS TETRA & GUEUCHE BLANC (AUSTRIA)XPICCOLA NERA (ITALY) & 19.96 \\
\hline
\end{tabular}

dendrogram described in Fig. 7, where some of these doubtful accessions are clearly not belonging to the Georgian branch. Particularly:

1. The variety Tsulukidzis Tetra, highlighted a strict relationship with the very well known Gouais Blanc. Gouais Blanc is a variety widespread in the Middle Ages in North Eastern France (Viala and Vermorel 1910), synonymous of Heunisch weiss variety, cultivated in Austria and, in the past, widely cultivated in Central Europe and especially in Dalmatia. Gouais Blanc has been proposed as a candidate for the grape given to the Gauls by Marcus Aurelius Probus (Roman Emperor 276-282), native of Pannonia. Another hypothesis claims the origin of Gouais Blanc specifically in Croatia (or Pannonia), but the Vitis International Variety Catalogue currently lists it as originating from Austria, which should probably be interpreted as "likely to originate somewhere in Central Europe." In the late 1990s, DNA fingerprinting at the University of California (Davis, CA, USA) identified Gouais Blanc as the ancestor of a large number of classical European grape varieties (Bowers et al. 1999). This sounds surprising given the old division into Frankish and Hunnic grape varieties used in the Germanic world, as it meant that the prototype simple Hunnic grape was, in fact, an ancestor to most of the noble Frankish grapes. Tsulukidzis Tetra was found to be sharing alleles in PO or sibling fashion also with other Austrian and Italian varieties, and according to the genetic distances defined in Fig. 6, it probably belongs to the western European viticulture, suggesting that the cited variety is not autochthonous from Georgia. The questionable origin of 
Tsulukidzis Tetra was already evidenced by some Georgian ampelographers (Cholokashvili 1938, 1939; Mirotadze and Bregvadze 1972; Ramishvili 1986) that considered this variety not autochthonous to Georgia and belonging to other European7 countries, despite other Georgian ampelographers convinced of the Georgian origin of this variety (Ketskhoveli et al. 1960; Tsertsvadze 1989; Ramishvili 2001). Particularly, according to Ramishvili (1986), it has to be considered as a synonym of the Spanish cultivar known as Albillo, also named Albillo Krismki, introduced in Georgia during the nineteenth century, but Tabidze (cit. in Mirotadze and Bregvadze 1972) supposed that it should be considered as derived from Pedro Ximenez Spanish cultivar and introduced in Georgia from Crimea. Our data are not able to support the synonymy supposed by the two authors but seem to confirm that Tsulukidzis Tetra is not a Georgian native variety. Moreover, the variety seems to have found a favorable environment in this country, and the probable first degree relationship with Gouais Blanc elevates its viticultural standing, becoming a half sibling of very famous international vines such as Chardonnay, increasing the interest and the need of a deeper investigation regarding this variety and the search of other putative Georgian candidates linked to Gouais Blanc offsprings.

In at least three other cases, our investigation led us to identify cases of a doubtful Georgian origin: Kharistvala Kolkhuri, Portoka, and Asuretuli Shavi.

2. Kharistvala Kolkhuri performs ampelographical traits (leaf shape, berry skin color, and plant habitus) not typical for the Georgian accessions, suggesting that a foreign origin could be involved and this might also explain the existence of a strict relationship with French varieties. The DNA fingerprinting confirmed ampelographic hypotheses about a foreign origin. The variety known as Portoka seems to have the same origin as Kharistvala Kolkhuri (same foreign varieties involved in the PO relationship); mostly, we have to highlight that no indication of the existence of this variety was found in the Georgian ampelography earlier than the one reported by Tsertsvadze (1988).

3. The case of the variety known as Asuretuli Shavi that has a relationship with the ancient Greek variety Rhoditis is also interesting. Asuretuli Shavi is a blackberried female variety from the Southern Georgia. According to Cholokashvili (1939) and Ortoidze et al. (2010), its origin is due to the discovery made by a German colonist within the period $1825-1845$ in the woodland close to the village Asureti (Marneuli district, South Georgia) of a wildly growing, red-fruiting, and high-yielding plant. Nicolau and Michos (2009) described Rhoditis as a variety documented in Greece since the ninth century, hermaphrodite and with various biotypes. The contact of Georgian and Greek varieties is supported by the long history of communication between the two countries as previously reported.

For some of the Georgian varieties where foreign cultivars were involved, FaMoz software also evidenced putative parent couples, and for the varieties which historical information and ampelography do not support a Georgian origin (Portoka, Tsulukidzis Terta, Kharistvala Kolkhuri, and Asuretuli Shavi), the two individuals indicated as putative parents weren't Georgian, confirming that those varieties were probably imported in Georgia.

On the other side, the cases of relationships with neighboring countries (Table 2) regard principal varieties considered a part of the Russian, Iranian, Syrian, and Armenian viticulture very interesting. Of particular interest seems to be the role played by the variety Ganziandy (traditionally cultivated in Armenia) which, in some cases, combined with Georgian varieties, has a first degree relationship with some of the varieties analyzed in this work (Buera, Gomis Tetri, Mskhviltvala Tetri, and Bzvanura). Ganziandy is a wine variety, but little information is given in the Vitis International Variety Catalogue or in the European Vitis Database and even the recent Black Sea Ampelography (Del Zan et al. 2009) reports no description. Based on the USSR Ampelography (1966), the variety Gandziandy is a synonym of the Armenian wine variety Lalvari. The meaning of Gandziandy is not known, while the name Lalvari comes from a mount in the Armenian Lori Region. It is a rare variety, spread in the northeast of Armenia and not available in the South Ararat Valley (G. Melyan, personal communication). Lori is a border region of Georgia. This might explain why Ganziandy is present in the constitution of the Georgian ampelographical platform.

According to FaMoz, output the black berry wine variety Assylkara from Dagestan (Russia) seems to share a relationship with two Georgian varieties: Marguli Sapere and Maghlari Shavi. Dagestan, located in the north slopes of the Great Caucasian Mountains and neighbor to Georgia, is the most important viticultural region of Russia due to richness of grape germplasm. Asylkara is one of the oldest varieties of the North Caucasus (Stavropol' Krai, Dagestan), cultivated nowadays only in limited areas (18 ha) (Troshin and Radchevskii 2005). According to Marchenko and Peitel' (Ampelography 1946-1970), the variety Asylkara was probably introduced from the South Caucasus in the beginning of grape cultivation in the basin of river Terek.

Under this point of view, our indications, derived from SSR data and analyzed with the FaMoz software, correctly evidenced those varieties with a questionable origin, contributing to better knowledge on Georgian local germplasms and on those 
varieties needing a deeper investigation to verify their Georgian origin.

\section{V. vinifera silvestris state of health in Georgia}

The investigation carried allows addition of few considerations also on wild grapevine in Georgia, even if this is not the topic of the paper. The survey on Georgian wild grapevines has a long-standing history (beginning in the $60 \mathrm{~s}$ of the past century) and is still in progress due to the activity of the Georgian Institute of Horticulture, Viticulture, and Oenology. All data obtained in these years were useful for the description of the main ecological traits regarding the typical habitat of wild grapevines in Georgia, which was very similar to the traditional environment found in all the other countries recording the presence of $V$. vinifera silvestris. As in other countries, it is quite difficult to find real populations: the common scenario is to identify sparse individuals. Among the 10 different places of collection, just for four of them were more than one individual recorded. In these four cases, the number of individuals for population varied from two to five. The sex ratio of all the samples investigated was near 1 with little prevalence of males on females, and if we consider the same ratio in each of the four populations identified (Online resources 1a), the proportion is respected with the only exception of Misaktieli population, where only females were accounted. However, we must underline that the limited number of individuals per population do not make these data robust enough to venture any conclusions on the fitness of each population and on their evolution. In addition, we must underline that till now only the western part of Georgia was interested in this kind of investigations. West Georgia is the most humid part of the country, thus harboring more vegetation than East Georgia, but in the next years, a deep survey also in the eastern part will be carried out in the frame of the European COST FA1003 project. This will be particularly useful not only to complete the description of the ecology of wild grapevine in Georgia but also to offer contribution to healthy aspects of this subspecies, especially regarding the state of health in relation to the major pests affecting $V$. vinifera species: Phylloxera (Daktulosphaira vitifoliae Fitch).

Despite belonging to the same species, Georgian silvestris individuals seem to be untouched by this pest. One of the most recent works published on this topic (Ocete Rubio et al. 2012) has verified the existence of disease symptoms in wild individuals only when the pest is directly and artificially inoculated. In the natural, wild environment, all the plants analyzed did not perform any symptom of the infestation. One of the reasons could be linked to edaphic conditions of the soils were the plants are hosted in the wild. Actually, V. vinifera silvestris lives in humid environments were the anoxic conditions of the soil are unsuitable for Phylloxera.

\section{Conclusions}

This work provides the first high-throughput analysis of Georgian viticulture and the first example of utilization of one of the more complete and exhaustive grapevine germplasm collections (Vassal Repository) as comparison base to verify and check out mistakes, synonyms, or false attributions in the frame of the viticulture of one of the most important countries for grape domestication. The work was carried out describing the genetic structure of cultivated and wild compartments present in Georgia and speculating about the existing links and admixtures with viticulture of other countries, trying to offer a contribution to the reconstruction of domestication events and routes that have designed modern viticulture in the way it is today. Our work offered strong confirmation to the most interesting and recent works addressing these issues. Particularly, the work of Myles et al. (2011) lead to conclusions about the role played by Caucasian countries that find here an important confirmation, and since the work cited had just few wild samples (\# 5) and no cultivated varieties belonging to Georgia, our common conclusions based on other molecular markers (SSRs vs. SNPs) are particularly interesting, especially the ones regarding silvestris samples and their admixture with cultivated varieties.

All the results reported in the work are consistent with each other and all lead to the same description of Georgian viticulture as an example of an extremely conserved germplasm but, at the same time, it seems that no genetic erosions or drift have affected its structure. Evidences drawn in this work seem also to highlight a low degree of genetic exchanges with the rest of the world viticulture, even if not all the Georgian germplasm was inserted in our research. According to the Ampelography of Georgia (Ketskhoveli et al. 1960), Georgian germplasm is constituted by 525 varieties, among which most are characterized by the main ampelographical descriptors, so the number of accessions accounted in this work is just representative of the huge number of putative varieties. This last consideration does not invalidate our discussion and conclusions on Georgian viticulture. Oppositely, the high level of heterozygosis, the strict link with the terroir, and the existence of relationships with varieties from abroad not affecting the structure and characteristics of Georgian germplasm, achieved on a relatively low number of samples, are expected to increase when enlarging the sampling.

The avoidance of genetic assortment loss makes Georgian viticulture particularly interesting in the frame of genetic and agronomic studies. Vine cultivation and pest 
diseases in the past had not affected the germplasm structure of Georgian cultivated varieties as in other countries.

This makes the country viticulture challenging when thinking at the possibilities offered by breeding for quality and/or resistance. Actually, in the last years, several Georgian native varieties were inserted in breeding programs in Georgia as in other foreign countries. As a result, 193 new varieties were bred in 15 countries, with the contribution of 13 Georgian native varieties (Vakhtangadze et al. 2010). Particularly interesting under this point of view seems to be the history of the Georgian cv Saperavi extensively used in Ukraine breeding programs (Goryslavets et al. 2010).

One of main constrains in the development of this kind of research is the few information (and for few varieties) achieved about agronomical characterization for Georgian varieties and the unavailability of this knowledge in European languages. This work aspires to highlight potentialities hidden in this unexplored germplasm and should be considered as a first step in the frame of increasing genetic assortments and variability for different purposes.

The search of information regarding varieties from Caucasian viticulture is also affected by the limited number of varieties from the region available in European germplasm collections. This limit, combined with the narrow varieties belonging to eastern European countries present in the same collections, affects also the search of possible relationships involving Georgian viticulture, making our results a possible underestimation of the real situation. The maintenance of Georgian and other Caucasian country viticulture is the first step, avoiding the loss, experimented in other countries, of local assortments. Proper knowledge of these genetic resources should prevent the loss of biodiversity. Also, the presence of new alleles found in the Georgian grapevine is a proof of its large diversity and should encourage more research for comprehension of genetic or metabolic features governing quality or resistance.

The need for improving the knowledge on grapevine genetic resources (cultivated and wild) is well underlined by the existence, in the last 10 years, of several research projects devoted to the exploration and characterization of biodiversity in this species. One of the last and most important is the GrapeGen06 European project (Bacilieri 2008; Bacilieri et al. 2010), where Georgia was included in addition to European countries, as a mark of the importance that the scientific community tributes to the grape germplasm of the country.

In crop species, only a small portion of the resources and of the genetic diversity conserved in germplasm is used by agricultural practice. To better investigate genetic resources hidden in the spontaneous flora and in the genomes of cultivated plants highly heterozygous as grapevine, field collections are the best strategy to verify single plant peculiar characteristics and to plan conservation and breeding strategies. This kind of maintenance is quite expensive and good management of genetic resources selected to be represented in the collection should be made. Only true to type material should be taken into account to optimize the number of genotypes. This is another issue that this work has started to consider for Georgian viticulture. The presence of accessions with the same name (or similar) in our group of samples and the existence of different fingerprints highlighting that they are not the same variety make urgent a collaborative work among germplasm repositories to rationalize the collections by developing proper common strategy also aimed to define and replicate core collections. This scenario and the results obtained and discussed in this work were the starting point for the definition of an EU-COST (http:// www.cost.esf.org/domains_actions/fa/Actions/grapevine) project devoted to "East-west collaboration for grapevine diversity exploration and mobilization of adaptive traits for breeding." The new challenge raised in these last years is to explore the poorly known genetic resources still present in the presumed area of domestication for grapevine (southeastern Europe and particularly the Caucasus) and still enclosing untapped diversity and richness. The aim is to enable researchers from east and west European countries to introduce innovative areas of research at the European level, creating beneficial knowledge, long-term conservation, and greater quality of grape production in Europe.

Acknowledgments The authors are grateful to two anonymous reviewers for their valuable comments and suggestions. This study is a joint publication of the COST Action FA1003 "East-west Collaboration for Grapevine Diversity Exploration and Mobilization of Adaptive Traits for Breeding."

\section{References}

Alleweldt G, Possingham JV (1988) Progress in grapevine breeding. Theor Appl Genet 75:669-673

Ampelography (1946-1970) Ampelography of the Soviet Union in ten volumes. Editors: A.M. Frolov-Bagreev AM for vols 1-6. (19461956) and Negrul AM for vols 7-10 (1963-1970). Pischepromizdat, Moscow (in Russian)

Anzani R, Failla O, Scienza A, Campostini F (1990) Wild grapevine (Vitis vinifera var. silvestris) in Italy distribution, characteristics and germplasm preservation-1989 report. Vitis Special Issue, pp 97-112

Aradhya MK, Gandl GS, Prins BH, Boursiquot JM, Walker MA (2003) Genetic structure and differentiation in cultivated grape Vitis vinifera L. Genet Res 81:179-192

Arnold C (2002) Ecologie de la vigne sauvage, Vitis vinifera L. ssp sylvestris (Gmelin) Hegi, dans les forêts alluviales et colluviales d'Europe. PhD Thesis, University of Neuchâtel, Switzerland

Arroyo-García R, Ruiz-García L, Bolling L, Ocete R, Lopez MA, Arnold C et al (2006) Multiple origins of cultivated grapevine (Vitis vinifera L. ssp. sativa) based on chloroplast DNA polymorphisms. Mol Ecol 15:3707-3714

Azuma A, Kobayashi S, Mitani N, Shiraishi M, Yamada M, Ueno T, Kono A, Yakushiji H, Koshita Y (2008) Genomic and genetic 
analysis of Myb-related genes that regulate anthocyanin biosynthesis in grape berry skin. Theor Appl Genet 117:1009-1019

Bacilieri R (2008) GrapeGen06 - management and conservation of grapevine GR. Biovers Newsl Eur 34:16

Bacilieri R, Maghradze D, Grando S, Pejic I, Maul E, Munoz G, Eiras-Dias J, Schneider A, Boselli M, This P (2010) Conservation, characterisation and management of grapevine genetic resources: the European project Grapegen06. Materials of OIV 33rd World Congress on Vine and Wine. Tbilisi, Georgia. www.oiv2010.ge

Bowers J, Bousiquot JM, This P, Chu K, Johansson H, Meredith CP (1999) Historical genetics: the parentage of Chardonnay, Gamay and other wine grapes of northeastern France. Science 285:15621565

Catholicism (1980) Catholicism in Georgia. In: Encyclopedy of Georga. Tbilisi, 5:319 (in Georgian)

Census (2004) Materials of the first National Agricultural Census of Georgia made in 2004. http://www.geostat.ge/index.php?action= page\&p_id=662\&lang=eng Accessed 24 Oct. 2011

Chilashvili L (2004) The vine, wine and the Georgians. Tbilisi. (in Georgian)

Chkhartishvili N, Maghradze D (2012) Viticulture and winemaking in Georgia. In: Maghradze D, Rustioni L, Scienza A, Turok J, Failla O (eds) Caucasus and Northern Black Sea Region. Vitis, Special Issue, pp 169-176

Chkhartishvili N, Maghradze D, Gogishvili K, Tchipashvili R (2005) CWR: grapevine, small and minor fruits of Georgia (The Caucasus). The first international conference on Crop Wild Relative conservation and use. Agrigento, Sicily, Italy

Cholokashvili S (1938) Materials for Georgian grapevine varieties of XII-XIII centuries. In: Djavakhishvili I (ed) Material culture of Shota Rustaveli's epoch. Tekhnika da shroma publishers Tbilisi, pp 60-105 (In Georgian)

Cholokashvili S (1939) Handbook for viticulture. Ganatleba Publishers. p 478 (In Georgian)

Cipriani G, Spadotto A, Jurman I, Di Gaspero G, Crespan M, Meneghetti S, Frare E, Vignani R, Cresti M, Morgante M, Pezzotti M, Pe E, Policriti A, Testolin R (2010) The SSR-based molecular profile of 1005 grapevine (Vitis vinifera L.) accessions uncovers new synonymy and parentages, and reveals a large admixture amongst varieties of different geographic origin. Theor Appl Genet 121:1569-1585

Cockerham CC, Weir BS (1983) Variance of actual inbreeding. Theor Popul Biol 23:85-109

Costantini L, Kvavadze E, Rusishvili N (2005/2006) The antiquity of grapevine cultivation in Georgia. J. 'Vazi da Ghvino' (Vine and Wine). Tbilisi 1-2:62-70

Cunha J, Balerias-Couto M, Cunha JP et al (2007) Characterization of Portuguese populations of Vitis vinifera L ssp. sylvestris (Gmelin) Hegi. Genet Resour Crop Evol 54:981-988

Dakin EE, Avise JC (2004) Microsatellite null alleles in parentage analysis. Heredity 93:504-509

De Andrés MT, Benito A, Perez-Rivera G, Ocete R, Lopez MA, Goforio L, Cabello F, Martinez-Zapater JM, Arroyo-Garcia R (2012) Genetic diversity of wild grapevine populations in Spain and their genetic relationships with cultivated grapevines. Mol Ecol 21:800-816

De Candolle A (1883) Origine des plantes cultivées. Paris (in French)

Del Zan F, Failla O, Scienza A (2009) La vite e l'uomo-dal rompicampo delle origini al salvataggio delle reliquie, 2 nd edn. ERSA (in Italian)

Di Pasquale G (2010) Vinum nostrum - art, science and myths of wine in ancient Mediterranean cultures. Catalogue of the exhibition organised in the Museo degli Argenti Palazzo Pitti at 20 July 2010-30 Aprile 2011. Florence. Printed by Giunti Industrie Grafiche S.p.A.-Prato. p 382
Di Vecchi Staraz M, Boselli M, Gerber S, Laucou V, Lacombe T, This P, Varès D (2007) FaMoz: a software for large scale parentage analysis in Vitis vinifera L. species. ISHS Acta Horticult 754:79-84

Di Vecchi M, Laucou V, Roux C, Bruno G, Bourse T, Varés D, et al. (2006) Contribution to the analysis of wild grape (Vitis vinifera ssp. sylvestris (Gmelin)) populations in France and Italy: genetic structure of populations and evidence of gene flux. In: 9th Conference on Grape Genetics and Breeding. Udine, (Abstract)

Doligez A, Adam-Blondon AF, Cipriani G, Laucou V, Merdinoglu D, Meredith CP, Riaz S, Roux C, This P, Di Gaspero G (2006) An integrated SSR map of grapevine based on five mapping populations. Theor Appl Genet 113:369-382

Dzidziguri L (1995) Grapevine and Colchis. J. "Vazi da Ghvino" (Vine and Wine). Tbilisi 1-2(18-19):73-78 (in Georgian)

Emanuelli F, Battilana J, Costantini L, Le Cunff L, Boursiquot JM, This P, Grando MS (2010) A candidate gene association study on muscat flavor in grapevine (Vitis vinifera L.). BMC Plant Biol $10: 241$

Felsenstein J (1989) Phylogeny inference package. Cladistics 5:164-166

Forni G (2012) The origin of "Old World" viticulture. In: Maghradze D, Rustioni L, Scienza A, Turok J, Failla O (eds) Caucasus and Northern Black Sea Region. Vitis, Special Issue, pp 27-38

Forni G, Failla O (2010) I destini intrecciati di vite e uomo: Le aree di domesticazione della vite. Origine (edizioni L'Informatore Agrario spa). 1:17-21 (in Italian)

Frare E, Costacurta A, Giannetto S, Meneghetti S, Crespan M (2011) Identification of Armenian and Georgian Vitis ssp. cultivars by SSR markers and molecular relationship with European grapevines. Le Bulletin de L'OIV 83:475-484

Genoa (1979) Colonies of genoa on the North Black Sea cost. In: Encyclopedy of Georga. vol. 3. Tbilisi. pp 58 (in Georgian)

Gerber S, Chabrier P, Kremer A (2003) FaMoz: a software for parentage analysis using dominant, codominant and uniparentally inherited markers. Mol Ecol Notes 3:479-481

Glonti T (2010) Traditional technologies and history of Georgian wine. Materials of OIV 33d World Congress on Vine and Wine. Tbilisi, Georgia, p 7. www.oiv2010.ge

Goryslavets S, Risovanna V, Bacilieri R, Hausman JF, Heuertz M (2010) A parentage study of closely related Ukrainian wine grape varieties using microsatellite markers. Tsitol Genet 44:95-102

Grassi F, Labra M, Imazio S, Spada A, Sgorbati S, Scienza A, Sala F (2003a) Evidence of a secondary grapevine domestication centre detected by SSR analysis. Theor Appl Genet 107:1315-1320

Grassi F, Imazio S, Failla O, Scienza A, Ocete Rubio R, Lopes MA, Sala F, Labra M (2003b) Genetic isolation and diffusion of wild grapevine Italian and Spanish populations as estimated by nuclear and chloroplast SSR analysis. Plant Biol 5:608-614

Hamblin MT, Warburton ML, Buckler ES (2007) Empirical comparison of simple sequence repeats and single nucleotide polymorphisms in assessment of maize diversity and relatedness. PLoS One 12:1367

Harter AV, Gardner KA, Falush D, Lentz DL, Bye RA, Rieseberg LH (2004) Origin of extant domesticated sunflowers in eastern North America. Nature 430:201-205

Hehn V (1870) Kulturpflanzen und Hausteire in ihren Ubergang aus Asien nach Griechenland und Italien, I auflage. (VIII auflage, 1911). Berlin (in German)

Hoffman A, Hoffman JI, Amos W (2005) Microsatellite genotyping errors: detection approaches, common sources and consequences for paternal exclusion. Mol Ecol 14:599-612

Hvarleva T, Russanov K, Lefort F, Tzvetkov I, Atanassov A, Atanassov I (2004) Genotyping of Bulgarian Vitis vinifera L. cultivars by microsatellite analysis. Vitis 43:27-34

Ibàňes J, De Andrès MT, Molino A, Borrego J (2003) Genetic study of Spanish grapevine varieties using microsatellite analysis. Am J Enol Vitic 54:22-30 
Imazio S, Labra M, Grassi F, Scienza A, Failla O (2006) Chloroplast microsatellites to investigate the origin of grapevine. Genet Resour Crop Evol 53:1003-1011

Japaridze O, Javakhishvili A (1971) The oldest culture for farming of habitants on the territory of Georgia. Tbilisi (In Georgian)

Ketskhoveli N, Ramishvili M, Tabidze D (1960) Ampelography of Georgia. Georgian Academy of Science, Tbilisi, Georgia. (In Georgian and Russian)

Kighuradze T (2000) Georgia - the cradle of viticulture and winemaking. J. "Vazi da Ghvino" ('Grapevine and Wine'). Tbilisi. pp 27-29 (in Georgian)

Kokrashvili Z (2004) Georgian phenomenon - wine and divinity of wine Badagoni. Tbilisi (in Georgian, English, Russian)

Kolenati FA (1846) Versuch einer systematischen Anordnung der in Grusinien einheimischen Reben nebst einem oekonomischtechnischen Anhange. Bull Soc Sci Nat Moscou 19:283-371

Kvevri (2011) The art of making Kvevri. In: Kheloba kartuli. http:// www.kvevri.org/en/the-art-of-making-kvevri.html Accessed 30 October 2011

Larrea A (1978) Vides americanas portainjestos. Ministerio de Agricoltura, Madrid, in Spanish

Laucou V, Lacombe T, Dechesne F, Siret R, Bruno JP, Dessup M, Dessup T, Ortigosa P, Parra P, Roux C, Santoni S, Varés D, Péros JP, Boursiquot JM, This P (2011) High throughput analysis of grape genetic diversity as a tool for germplasm collection management. Theor Appl Genet 122:1233-1245

Levadoux L (1956) Les populations sauvages et cultives des Vitis vinifera L. Ann Amél Plantes 1:59-118

Licheli V (2007) Old Georgian wine making - the archaeological interpretation. Colloque international la Géorgie et la France: deux civilisations du vin. Les travaux du colloque. Tbilisi. pp 25-42 (in Georgian)

Lijavetzky D, Ruiz-García L, Cabezas JA, De Andrés MT, Bravo G, Ibáñez A, Carreño J, Cabello F, Ibáñez J, Martínez-Zapater JM (2006) Molecular genetics of berry colour variation in table grape. Mol Genet Genomics 276:427-435

Lomouri N (1962) Greece colonization of Colchis. Encyclopedy of Georga. Tbilisi, 1:487-488 (in Georgian)

Lopes MS, Mendoc AD, Rodrigues do Santos JE, Eiras-Dias JE, da Camara Machado A (2009) New insights on the genetic basis of Portuguese grapevine and on grapevine domestication. Genome 52:790-800

Lortkipanidze O (1980) The kingdom of Colchis. Encyclopedy of Georga. Tbilisi, 5:596-597 (in Georgian)

Maghradze D (2008) Status of Vitis collections in Georgia. Reports of a working group on Vitis. The first ECP/GR meeting, 12-14 June, Palić, Serbia and Montenegro, held in 2003, pp 75-76

Maghradze D, Turok J (2012) Project of Bioversity International on conservation and sustainable use of grapevine genetic resources in the Caucasus and northern Black Sea region: activities and results. In: Maghradze D, Rustioni L, Scienza A, Turok J, Failla O (eds) Caucasus and Northern Black Sea region. Vitis, Special Issue, pp $17-26$

Maghradze D, Imazio S, Failla O (2006a) Risorse genetiche della vite in Caucaso e Mar Nero. L'Informatore Agrario 49:59-61, in Italian

Maghradze D, Mdinaradze I, Chkhartishvili N, Gogishvili K, Chipashvili R (2006) Inventory of wildly growing grapevine in Eastern Georgia. J. 'Vinodelie i Vinogradarsvo' (Winemaking and Viticulture). Moscow 6:39 (in Russian)

Maghradze D, Failla O, Turok J, Amanov M, Avidzba A, Chkhartishvili N, Costantini L, Cornea V, Hausman JF, Gasparian S, Gogishvili K, Gorislavets S, Maul E, Melyan G, Pollulyakh A, Risovannaya V, Savin G, Scienza A, Smurigin A, Troshin L, Tsertsvadze N, Volynkin V (2009a) Conservation and sustainable use grapevine genetic resources in the Caucasus and Northern Black Sea area. ISHS Acta Horticult 827:155-158
Maghradze D, Rossoni M, Imazio S, Maitti C, Failla O, Del Zan F, Chkhartishvili N, Scienza A (2009b) Genetic and phenetic exploration of Georgian grapevine germplasm. ISHS Acta Horticult $827: 107-114$

Maghradze D, Failla O, Bacilieri R, Imazio S, Vashakidze L, Chipashvili R, Mdinaradze I, Chkhartishvili N, This P, Scienza A (2010) Georgian Vitis germplasm: usage, conservation and investigation. Le Bulletin de L'OIV 83:485-596

Maghradze D, Rustioni L, Scienza A, Failla O (2012) Phenological diversity of Georgian grapevine cultivars in Northern Italy. J Am Pomol Soc 66:56-67

McGovern PE (2003a) Ancient wine. The search for the origins of viniculture. Princeton University Press, Princeton

McGovern PE (2003b) (Interview). 8,000-year-old wine unearthed in Georgia. The Independence. 28 December, 2003

Mirotadze A, Bregvadze M (1972) Grapevine varieties of RatchaLechkhumi. Publishing House Sabtchota Sakartvelo, Tbilisi, in Georgian

Myles S, Boyko AR, Owens C et al (2011) Genetic structure and domestication history of the grape. Proc Natl Acad Sci 108:3530-3535

Negrul AM (1938) Evolution of cultivated forms of grapes. Paris

Negrul AM (1946) Origin of cultivated grapevine and its classification. Ampelography of the Soviet Union. Editor of Chief FrolovBagreev AM, (ed) Pishchepromizdat, Moscow 1:159-216 (in Russian)

Nei M (1978) Molecular evolutionary genetics. Columbia University Press, New York

Nicolau N, Michos V (2009) Roditis. In: Del Zan F, Failla O, Scienza A (eds) La vite e l'uomo-dal rompicampo delle origini al salvataggio delle relique, 2nd edn. ERSA, Gorizia, pp 628-630, in Italian

Ocete Rubio R, Ocete Rubio E, Ocete Pérez C, Pérez Izquierdo MA, Rustioni L, Failla O, Chipashvili R, Maghradze D (2012) Ecological and sanitary characteristics of the Eurasian wild grapevine (Vitis vinifera L. ssp. sylvestris (Gmelin) Hegi) in Georgia (Caucasian region). Plant Genet Resour 10:155-162

Ocete R, Gallardo A, Lara M, Lopez MA, Perez MA (2006) Una perspective historica sobre la crisis filoxerica y su impacto en el vinedo andaluz. Junta de Andalucia, Instituto Nacional de Investigation y formacion Agraria y Pesquera. Sevilla. (in Spanish)

Olmo HP (1995) The origin and domestication of the vinifera grape. In: McGovern PE, Fleming SJ, Katz SH (eds) The origin and ancient history of wine. Gordon \& Breach, Luxembourg, pp 31-43

Ortoidze T, Vashakidze L, Bezhuashvili M, Ramishvili N, Jigauri G (2010) Origin and peculiarities of rarely distributed grapevine variety Asuretuli Shavi. Materials of the 33d OIV Vine and Wine Congress. Tbilisi, Georgia, p 6. (http://www.oiv2010.ge)

Peakall R, Smouse PE (2006) GENALEX 6: genetic analysis in Excel. Population genetic software for teaching and research. Mol Ecol Notes 6:288-295

Ramishvili M (1986) The ampelography, 2nd edn. Publishing House Ganatleba, Tbilisi, p 620, In Georgian

Ramishvili R (1988) Wild grapevine of the trans-Caucasus. Tbilisi (in Russian)

Ramishvili R (2001) History of Georgian grapevine and wine. Tbilisi, Georgia. (in Georgian)

Riaz S, Garrison K, Dangl G, Boursiquot J, Meredith C (2002) Genetic divergence and chimerism within ancient asexually propagated wine grape cultivars. J Am Soc Hortic Sci 127:508-514

Rushishvili N (1990) Cultivated plants on the earliest dwelling of Georgia according to palaeobotanical investigations. Abstract for Doctor dissertation. Chisinau (in Russian)

Rusishvili N (2010) Grapevine culture in Georgia on basis of palaeobotanical data, 2nd edn. Publisher "Mteni" Association, Tbilisi, p 37. (In Georgian, Russian, English) 
Schaal B, Beck J, Hsu SC, Beridze T, Gamkrelidze M, Gogniashvili M, Pipia, Tabidze V, This P, Bacilieri R, Gotsiridze V, Glonti M (2010) Plastid DNA sequence diversity in a worldwide set of grapevine cultivars (Vitis vinifera L. subsp. sativa). Materials of the 33rd World Congress on Vine and Wine. Tbilisi. p 8. (www.oiv2010.ge)

Sefc KM, Lopes MS, Lefort F, Botta R, Roubelakis-Angelakis KA, Ibanez J, Pejic I, Wagner HW, Glossl J, Steinkellner H (2000) Microsatellite variability in grapevine cultivars from different European regions and evaluation of assignment testing to assess the geographic origin of cultivars. Theor Appl Genet 100:498-505

Sefc K, Steinkellner H, Lefort F, Botta R, Da Camara Machado A, Borrego Palanco L, Maletic E, Glössl J (2003) Substantial genetic contribution of local wild vines to European grapevine cultivars. Am J Enol Vitic 54:15-21

Sharden J (1711) Traveling in Georgia. (Translated by V. Barnov). Printed in 1931 (In Georgian)

Smouse PE, Peakall R (1999) Spatial autocorrelation analysis of individual multiallele and multilocus genetic structure. Heredity 82:561-573

Staroselski VA (1893) Grapevine varieties of the Caucasus - Shorapani and Kutaisi uezds of Kutaisi Gubernia. Materials on the ampelography of the Caucasus. 1:20 (in Russian)

This P, Lacombe T, Thomas MR (2006) Historical origins and genetic diversity of wine grapes. Trends Genet 22:511-519

Troshin LP, Radchevskii PP (2005) Recommended cultivars of grapevine for Russia. Publisher Vol'nyeMastera, Krasnodar, in Russian

Tsertsvadze N (1988) Determiner of grapevine varieties distributed in Georgia. Tbilisi (in Georgian)

Tsertsvadze N (1989) Classification of Georgian cultural grapevine. Publishing house "Sabtchota Sakartvelo", Tbilisi, in Georgian

Vakhtangadze T, Maghradze D, Dandurshvili N (2010) Participation of Georgian native varieties in grapevine breeding. Bull Acad Agric Sci Georgia 27:186-192, in Georgian
Vavilov NI (1926) Cemtry proiskhozhdenia kulturnikh rastenii (The centres of origin for cultivated plants). Trudi po prikladnoi botanike, genetike i selektsii. Proc Appl Bot Genet Plant Breed 16(2):133-137, in Russian

Vavilov NI (1931) Wild relatives of fruit trees of Asia part of the USSR and the Caucasus and problems of origin for fruit trees. (Selective works of Acad. N.I. Vavilov was used). 1960. 2:343-361. (in Russian)

Viala P, Vermorel V (1910) Traité general de Viticulture-Ampelographie. Eds. Masson et Cie, Paris

Vigouroux Y, Mitchell S, Matsuoka Y, Hamblin M, Kresovich S, Smith JSC, Jaqueth J, Smith OS, Doebley J (2005) An analysis of genetic diversity across the maize genome using microsatellites. Genetics 169:1617-1630

Vouillamoz JF, McGovern P, Ergul A, Sőylezoğlu G, Tevzadze G, Meredith CP, Grando SM (2006) Genetic characterization and relationship of traditional grape cultivars from Transcaucasia and Anatolia. Plant Genet Resour 4:144-158

Wagner HW, Sefc KM (1999) IDENTITY 1.0. Centre for Applied Genetics, University of Agricultural Sciences Vienna

Wagner AP, Creel S, Kalinowski ST (2006) Estimating relatedness and relationships using microsatellite loci with null alleles. Heredity 97:336-345

Ward JH (1963) Hierarchical grouping to optimize an objective function. J Am Stat Assoc 58:36-244

Zecca G, De Mattia F, Lovicu G, Labra M, Sala F, Grassi F (2010) Wild grapevine: silvestris, hybrids or cultivars that escaped from vineyards? molecular evidence in Sardinia. Plant Biol 12:558-562

Zinelabidine LH, Haddioui A, Bravo RG, Arroyo-García R, Martínez Zapater JM (2010) Genetic origins of cultivated and wild grapevines from Morocco. Am J Enol Vitic 61:83-90

Zohary D, Horf M (2000) Domestication of plants in the Old World. The origin and spread in West Asia, Europe and the Nile Valley. Oxford University Press, Oxford 